\title{
SCIENTIFIC APPROACH BASED TRANSLATION USED BY EFL JUNIOR HIGH SCHOOL TEACHER
}

\author{
N. M. Sumarningsih ${ }^{1}$, G. Batan ${ }^{2}$, L. D. S. Adnyani ${ }^{3}$ \\ ${ }^{1}$ Labda Karya Manunggal \\ 2,3 Universitas Pendidikan Ganesha \\ e-mail: sumarningsihnimade@gmail.com, igd.batan@gmail.com, luh_diah@yahoo.com
}

\begin{abstract}
This study was conducted as an attempt to investigate in what step of scientific approach the teachers most frequently use translation in English Language Teaching as well as to find out the teachers' reasons toward the use of translation in English Language Teaching based on scientific approach at SMP Negeri 4 Singaraja and SMP Negeri 5 Singaraja. It was conducted in qualitative research design. There were two teachers chosen as the subjects of study. The data were collected through audio recording the teaching and learning process and interviewing the subjects of study, while the techniques of analyzing data were done descriptively following the four processes according to the theory of Miles \& Huberman (1984), namely: data collection, data reduction, data display, and conclusion drawing. The results of analysis indicated that the teachers most frequently used translation in exploring step of scientific approach. In addition, there were seven teachers' reasons found in relation to the use of translation in the classroom, namely to help the students' difficulty in: (1) understanding the instruction given by the teacher, (2) understanding the English vocabulary, (3) asking something in English, (4) understanding the tenses or grammar, (5) understanding the material deeply, (6) doing the task, and (7) presenting their work. The related parties interested in the same area of the research should give deeper concern in doing wider range of aspects involved in further study.
\end{abstract}

Keywords: Translation, ELT, translation, scientific approach

\section{INTRODUCTION}

The education system in Indonesia is organized by the Ministry of National Education and commanded by law Number 20 Year 2003 about the National Education System (Ahmad, 2014). One of the education components, which is organized is called curriculum; the newly introduced and implemented one in Indonesia is 2013 Curriculum (Nur and Madkur, 2014).

One component characterized the emergence of 2013 Curriculum is scientific approach (Tantra, 2015). Scientific approach is an approach that applied a scientific process and it has five steps, namely: (1) observing, (2) questioning, (3) exploring, (4) associating, and (5) communicating (Gani and Mahjaty, 2017). Each step of scientific approach has its own activity.
Suharyadi (2013); Musfiqon and Nurdyansyah (2015); Wahyudin and Sukyadi (2015); Atmarizon and Zaim (2016); Munir (2015); Kemdikbud (2013) and Hosnan (2014) as cited in Zaim (2017) define each step of scientific approach. In this first step, observing, the teachers take two main responsibilities, namely: giving the students an opportunity to do an observation and facilitating or training the students in their observation. Some activities that can be done in the observing are reading, listening, scrutinizing, and observing with or without a tool. The competency that can be developed in this step is observing in training sincerity, thoroughness, and ability in finding the information. In other words, observing can lead the students to the construction of knowledge. In accordance to 
the four skills in learning English, observing refers to listening and reading skill.

In the second step, questioning, the teachers give a chance to the students to build or encourage their curiosity and critical thinking about what they will learn. It can be done by asking a question about an information that is difficult to understand or asking a question for an additional information. It make the teacher has to be able to make the students curious. The competency that can be developed in the questioning step is students' creativity, curiosity, ability to formulate the question in order to develop the critical thinking skill and formation of life long learner. It means that questioning is the second step in scientific approach, which aims at building the students' critical thinking. In accordance to the four skills in learning English, questioning refers to speaking and writing skill.

The third step, exploring, is an activity in which the teacher applies a collaborative learning (the students discuss something with their friends) in order to explore additional knowledge or information. There are some activities that can be done in this step such as doing an experiment, reading any learning sources (document, object, book, internet media, and experiment), observing any objects and events, and interviewing. In this step, the students can develop their carefulness, honesty, ability in respecting the other opinion, ability in doing a communication, ability in gathering the information with any ways, and make the students become lifelong learner. In accordance to the four skills in learning English, experimenting refers to listening and reading skill.

The fourth step, associating, is a step in which the teachers ask the students to analyze what they have discussed and try to find the relation between one and another information. The other activity is the students are asked to draw a conclusion of the result of their analysis. In this case, the students are given a task by the teacher. Through this step of scientific approach, the students can develop their carefulness, honesty, hard work, ability to think deductively and inductively especially in making a conclusion. In accordance to the four skills of learning English, associating refers to reading and writing skill.

In the last step, communicating, the teachers asks the students to report, present, or share what they have done in the previous steps. The students' work can be in the form of oral or written text, chart, diagram, or picture. In the communicating, the students are given chance to develop their skill in giving opinion and skill in using the target language optimally. In accordance to the four skills of learning English, communicating refers to speaking and writing skill. English teachers are expected to be able to apply the scientific approach in English Language Teaching (ELT) as well as the five scientific steps (Shofwan, 2016). One of many researchers in the previous studies asserts that more focus on learner learning rather than teacher teaching in English subject is not easy (Mattarima and Hamdan, 2011). In fact, the teacher who teaches a foreign language, spends more time to teach about the language and less time to check learners' understanding whether they can catch the meaning of language itself or not.

In implementing the newest curriculum named 2013 Curriculum, the decree of Minister of Education and Culture No. 69/2013 requires the integration of the scientific approach to all subjects in the school including English (Wahyudin and Sukyadi, 2015). There is an argument of the teacher and researcher that using English only is the key factor for the successful EFL classroom: it is well known as monolingual approach (Leonardi, 2011). However, others also suggest to use a bilingual approach where L1 also takes an essential role in the learning process (Harley, Cummins, Swain, and Allen, 1990 as cited in Leonardi, 2011).

The purposes of using L1 are: (a) L1 is used for ideational purposes such as in doing a translation, explanation, elaboration, and exemplification, (b) L1 is used for instructional purposes refers to the use of L1 for explaining an activity and its objectives, giving reference to special sources, directing classroom conversation, asking and answering question, and clarifying the ambiguities, (c) L1 is used for interpersonal purposes including the repetition

Lingua Scientia | 63 
of students' L1 utterances, reaction to the students' question, elicitation, evaluation of students' behavior, encouraging the students, presenting personal comments, and making humor, and (d) L1 is used for practical issues including for referring to the classroom equipment and administrative issues.

The use of L1 in teaching the students in EFL (English as Foreign Language) context is one of the major issues in the education field (Jadallah and Hasan, 2017). Teacher argues that when $L 2$ is fully used in the process of teaching English, the students will not understand what the teacher says clearly. In contrast, when the teacher uses L1 only, the students cannot improve their ability in using English. Jadallah and Hasan (2017) notes that in this situation, they reflect on the use of translation in ELT since it may contribute to the understanding of the students. They defend this practice of translation in the ELT is not as a means in itself, but as the way to improve student's better understanding.

Larson (1984:3) defines translation as a change of form; it is about a replacement of the source language into the target language. Oxford (1990) as cited in Pan and Pan (2012) explains translation as transforming the language of the receptor or target language into the source language or the reverse. Pan and Pan (2012) defines translation as a transfer between L1 (first language) and L2 (second language). Translation is also defined as an activity in interpreting the information, which is received in one language (L1) into another language (L2), and vice versa (L2 into L1) (AlMusawi, 2014). Furthermore, Karimian and Mohammadi (2015) highlight a switch from one language into another language freely is called as natural translation; it is most frequently done by people without working on it (translation).

The result of preliminary observation indicated it was clearly found that the English teachers, who taught the students at the seventh grade of these two Junior High Schools, still used translation in the process of teaching.

In accordance to the background above and relation to the phenomena found, the issues about applying scientific approach in the
2013 curriculum as well as the five scientific steps and the use of translation in ELT to help the students both understand the materials and develop their English skill, the researcher chose SMP Negeri 4 Singaraja and SMP Negeri 5 Singaraja as the setting for doing a study entitled "The Teacher's Use of Translation in English Language Teaching Based on Scientific Approach at SMP Negeri 4 and SMP Negeri 5 Singaraja".

Therefore, the problems of the study would be specifically formulated as: (a) In what step of scientific approach the teachers most frequently use translation from English to Indonesia and vice versa in English Language Teaching at SMP Negeri 4 Singaraja and SMP Negeri 5 Singaraja? and (2) What reasons do the teachers have toward the use of translation from English to Indonesia and vice versa in English Language Teaching based on scientific approach at SMP Negeri 4 Singaraja and SMP Negeri 5 Singaraja?

Moreover, the purposes of study were specifically formulated as: (a) To investigate in what step of scientific approach the teachers most frequently use translation from English to Indonesia and vice versa in English Language Teaching at SMP Negeri 4 Singaraja and SMP Negeri 5 Singaraja and (b) To find out the teachers' reasons toward the use of translation from English to Indonesia and vice versa by the teachers in English Language Teaching based on scientific approach at SMP Negeri 4 Singaraja and SMP Negeri 5 Singaraja.

\section{METHOD}

This study was conducted in qualitative research in an interactive approach. According to Fraenkel, Wallen, and Hyun (2012, p. 426), there are five characteristics of qualitative research. The first characteristic is it takes place in natural setting where the data source or phenomenon truly appears. In relation to this characteristic, the researcher of this study came to the setting of place directly in which the issue of using translation has been found there. The second characteristic is the data of qualitative research are described by using words and pictures not numbers. In relation to the second characteristic, the data obtained in

Lingua Scientia | 64 
this study were transcribed, described, and written by using words. The third characteristic concerns with the process. In relation to the third characteristic, the issue of translation in English Language Teaching (ELT) based on scientific approach was revealed through investigating the process use. The other characteristic is the data gained in qualitative research is analyzed inductively. In relation to this current study, the researcher here did not conduct the study to prove or disapprove theory of translation in ELT based on scientific approach. The last characteristic is meaning that focuses on the participants' perspective, response, perception, or reason. As mentioned above, the second research question of this study is the teachers' reasons toward the use of translation in ELT based on scientific approach.

This study was conducted at two Junior High Schools. The first is SMP Negeri 4 Singaraja and the second is SMP Negeri 5 Singaraja. In addition, the setting of place was also about the classes chosen by the researcher for conducting this study. Firstly, at SMP Negeri 4 Singaraja, from twelve classes at the seventh grade of students, there were only two classes chosen for conducting this study, which were 7A 1 and 7B 1 classes. Secondly, at SMP Negeri 5 Singaraja, from eleven classes at seventh grade of students, there were also two classes chosen by the researcher, which were $7 \mathrm{H}$ and $7 \mathrm{~J}$ classes. This study was conducted in academic year 2017/2018.

There were two teachers chosen as subjects of this study. The first one was an English teacher who teaches at seventh grade students at SMP Negeri 4 Singaraja. The second subject was an English teacher who teaches at seventh grade students at SMP Negeri 5 Singaraja. Furthermore, the object of this study was the translation from English to Indonesia and vice versa used by the subjects of this study in ELT based on scientific approach. Besides, the other object of this study were the teachers' reasons toward the use of translation from English to Indonesia and vice versa in ELT based on scientific approach at SMP Negeri 4 Singaraja and SMP Negeri 5 Singaraja.

There were two methods of data collection applied in this study; observation and interview. In this study, the researcher assigned herself as non-participant observation. According to Klein and Olbrecht (2011), nonparticipant observation means the researcher does not involve in the situation being observed. The researcher only gained the data based on the situation observed through audio recording. It was supported by the observation checklist used as one instrument of this study. In addition, the interview was carried out after observing the teaching and learning process in the classroom. It dealt with teachers' reasons of using translation in ELT based on scientific approach at SMP Negeri 4 Singaraja and SMP Negeri 5 Singaraja. This activity was also recorded by the researcher in order to obtain the detail answers from the interviewees. The interview was supported by interview guide in which it consisted of eight questions.

This study applied thematic analysis model for analyzing data. According to Miles \& Huberman (1994) as cited in Alhojailan (2012), there are three link stages in thematic analysis, which are data reduction, data display, and conclusion. In data reduction, the researcher transcribed every single word produced by the teacher and the students, which was appeared in the teaching and learning process. Then the researcher classified the words called as translation from English to Indonesia and vice versa produced by the teachers. This activity was done in order to obtain the data needed for answering the first research problem. Another activity was also done in order to answer the second research problem. It was about transcribing the finding of interviewing two teachers at SMP Negeri 4 Singaraja and SMP Negeri 5 Singaraja.

In data display, the researcher put the words, which were called as translation from English to Indonesia and vice versa into a table. The researcher categorized the translation from English to Indonesia and vice versa used in each step of scientific approach. Besides, the researcher made a frequency of the translation found in each step of scientific approach. In addition, for getting the clear answer of the second research problem, the researcher chose the reasons related to the use if translation in each step of scientific approach.

Lingua Scientia | 65 
After doing all of those techniques, the researcher concluded all findings. The first conclusion was about in what step of scientific approach the teachers most frequently used translation from English to Indonesia and vice versa based on its frequency. This conclusion refers to the answer of the first research problem. The other conclusion was a deep conclusion of teachers' reasons toward the use of translation from English to Indonesia and vice versa in English Language Teaching based on scientific approach at SMP Negeri 4 Singaraja and SMP Negeri 5 Singaraja. This conclusion refers to the answer of the second research problem.

\section{FINDING AND DISCUSSION}

The finding of the first research problem was concluded as the compilation of findings of eight meetings obtained by two teachers. Its complication was presented on the following table.

Table 1. Compilation of Findings of Eight Meetings Obtained By Two Teachers

\begin{tabular}{cccccc}
\hline $\begin{array}{c}\text { Steps of Scientific } \\
\text { Approach }\end{array}$ & $\begin{array}{c}\text { Average of } \\
\text { Teacher A at } \\
\text { School 1 }\end{array}$ & $\begin{array}{c}\text { Average of } \\
\text { Teacher B at } \\
\text { School 2 }\end{array}$ & Total & $\begin{array}{c}\text { Average of } \\
\text { Two } \\
\text { Teachers }\end{array}$ & $\begin{array}{c}\text { Percentage } \\
\text { (\%) }\end{array}$ \\
\hline Observing & 1.50 & 1.00 & 2.50 & 1.25 & $5.02 \%$ \\
Questioning & 2.50 & 0.25 & 2.75 & 1.37 & $5.52 \%$ \\
Exploring & 4.25 & 19.50 & 23.75 & 11.87 & $47.73 \%$ \\
Associating & 9.75 & 2.00 & 11.75 & 5.87 & $23.61 \%$ \\
Communicating & 4.75 & 4.25 & 9.00 & 4.50 & $18.09 \%$ \\
\hline
\end{tabular}

The table indicated the average score of translation from English to Indonesia and vice versa used by two teachers in each step of scientific approach. It showed that the average score of 1.25 in the observing step, 1.37 in the questioning step, 11.87 in the exploring step, 5.87 in the associating step, and 4.50 in the communication step. Therefore, it could be concluded that translation from English to Indonesia and vice versa was most frequently appeared in exploring step.

According to the theory of the implementation of scientific approach by Suharyadi (2013); Musfiqon and Nurdyansyah (2015); Wahyudin and Sukyadi (2015); Atmarizon and Zaim (2016); Munir (2015); Kemdikbud (2013) and Hosnan (2014) as cited in Zaim (2017), in exploring step, the students are asked to explore additional knowledge or information by doing some activities such as doing experiment, reading any learning sources, observing any objects and events, and interviewing. For instance, when the students read a book, they would find some texts that consisted of different tenses or grammar and some new English vocabularies that they might not understand. In this case, the students needed a tool, which could be used to help them to understand both grammar and new vocabularies. Therefore, translation used by the teachers could be used as a tool to solve this problem. The example of translation appeared in exploring step can be seen in table below.

Table 2. Examples of Translation Appeared in Exploring Step

\begin{tabular}{ccc}
\hline Teacher & Examples \\
\hline $\begin{array}{c}\text { Teacher A at } \\
\text { School } 1\end{array}$ & (37) & $\begin{array}{c}\text { Okay maybe, what do you know about descriptive text? Seperti apa teks deskriptif } \\
\text { yang kalian ketahui? }\end{array}$ \\
$\begin{array}{c}\text { Teacher B at } \\
\text { School } 2\end{array}$ & $\begin{array}{l}\text { (69) Is it clear? Sudah jelas ini? } \\
\text { Now, please find the difficult words of the text! Silahkan temukan kata sulit dalam } \\
\text { teks! }\end{array}$ \\
& $\begin{array}{l}\text { (127) Okay, look at paragraph two! Read a text carefully } 5 \text { minutes. Baca pelan-pelan } \mathbf{5} \\
\text { menit. }\end{array}$
\end{tabular}


In relation to the second research question, based on the result of the teachers' reasons toward the use of translation in ELT based on scientific approach, it was found that there were seven reasons, namely to help the students' difficulty in: (1) understanding the instruction given by the teacher, (2) understanding the English vocabulary, (3) asking something using English, (4) understanding the tenses or grammar, (5) understanding the material deeply, (6) doing the task, and (7) in presenting their work.

The first teachers' reason is in line with the study conducted by Campa and Nassaji (2009) as cited in Bozorgian and Fallahpour (2015), the teacher uses L1 for many purposes; one of them is for giving instruction to the students. Besides, according to the finding of a study conducted by Bozorgian and Fallahpour (2015), L1 is used by the teacher in ELT for several purposes; one of them is for instructional purposes. One example of instructional purposes is clarifying any confusion regarding instructions and saving time. In addition, according to Butzkamm (2003) and AlHinai (2011) as cited in Mahmutoğlu and Kicir (2013), one advantage of using translation is it helps the teacher to deliver the clear instruction.

The second teachers' reason was found in observing and exploring step. According to the theory of the implementation of scientific approach by Suharyadi (2013); Musfiqon and Nurdyansyah (2015); Wahyudin and Sukyadi (2015); Atmarizon and Zaim (2016); Munir (2015); Kemdikbud (2013) and Hosnan (2014) as cited in Zaim (2017), both observing and exploring step refer to listening and reading skill. Once the students listened to something, they would have some new English vocabularies. As well as when they read something, the students would get some new English vocabularies. Therefore, if what they listened to and what they read were in the form of translation, the students might find it easy to understand then memorize the new vocabularies found.

In relation to the third teachers' reason, the competencies that could be developed in the questioning step were students' curiosity, students' creativity, and students' ability to formulate the question in order to develop the critical thinking. As stated in the discussion of the first research problem, it would be difficult for the students to ask something in English since they had lack of English vocabulary. Due to this issue, the teacher had to help the students by using translation for both understanding the question itself and accustoming themselves with English language. It was in line with the theory of the role of L1 in ELT by Bozorgian and Fallahpour (2015). It was stated one of four purposes of using L1; L1 was used for instructional purpose in which it referred to asking and answering the question.

The fourth teachers' reason was found in applying the exploring and communicating step. As stated in the discussion of the first research problem, translation was needed to be used by the teacher in exploring step since the students would learn English grammar as existed in the learning sources they used.

In relation to the fifth teachers' reason, Explaining English subject material by using English might not be successful for improving the students understanding. In fact, the students felt stress because of the full English used by the teacher. Sometimes, using English only could make an ambiguous understanding for the students. Therefore, as the teachers, they had to decide to use a language that could be understood by the students easily. It was in line with Bozorgian and Fallahpour (2015) in which they state that L1 is used for instructional process such as clarifying ambiguities. It meant that in order to avoid the ambiguity, L1 was needed in explaining the material to all students.

In relation to the sixth teachers' reason, during doing the task, the students might find some difficulties to translate the material or the language learnt. As the teachers, they had to be as a controller and a facilitator for the students in every classroom activity. Once the students could get the point of the material and source used to do the task, they could finish the task optimally. Therefore, translation was needed to be used. Besides, it was also in line with a theory of the use of translation in instructional process by Nolasco and Arthur (1995) as cited

Lingua Scientia | 67 
in Dagilienè (2012). They explain one criteria of using translation in instructional process is translation activity can improve students' creativity and idea.

In relation to the last teachers' reason, in communicating step, the students were asked to report, present, or share what they have done in the previous step, associating step. However, for those who were shy learners would be afraid to speak using English. As stated in the discussion of the first research problem, this issue was in line with the theory of the reason of using translation by Notion (2001) as cited in Alrefaai (2013). It stated that using L1 is very beneficial especially for those who are shy learners and those who are not competent in using $\mathrm{L} 2$.

According to the findings mentioned above, it could be said that translation still appeared in the process of teaching English based on scientific approach. It indicated that the understanding of the students towards English itself was not good enough and still needed to be encouraged. Actually, the use of translation might affect to the students' skill in using English. Translation (L1) was useful when it was used to teach the young learners since it could help them understand the material easily. However, it was not useful for the adults since they might not improve their ability in using English.

The findings suggest that the teaching and learning process where L1 translation provided is still not effective yet. Therefore, in order to make it effective and improve the students ability in using English, the teachers should find and improve their strategy in the teaching and learning process such as minimize the use of translation (L1) yet maximize the use of target language as a language of instruction so that the learning goals could be achieved optimally.

Besides, the findings also indicate that the reasons of using translation are only related to the students' aspect. However, the teachers never told about their own skill in using English as a language of instruction. Therefore, the findings implied that the case of the teachers' ability in using English should also be studied by other researchers such as lecturers. In short, the findings of study implied that the teachers should improve their strategy in using target language as the language of instruction and the lecturer should do a study about the teachers' ability in using target language as the language of instruction.

\section{CONCLUSION}

According to the result analysis of study discussed above, it can be concluded that (a) translation from English to Indonesia and vice versa was most frequently used in exploring step by the teachers in ELT based on scientific approach at SMP Negeri 4 Singaraja and SMP Negeri 5 Singaraja with the average of 11,87 and (b) there were seven reasons found, namely to help the students' difficulty in: (1) understanding the instruction given by the teacher, (2) understanding the English vocabulary, (3) asking something using English, (4) understanding the tenses or grammar, (5) understanding the material deeply, (6) doing the task, and (7) presenting their work.

In addition, the researcher suggested the further researcher to make an improvement in conducting the further study. Those suggestions were (1) providing longer time, (2) choosing additional setting of place as possible, (3) expanding the subject of study, (4) expanding the object of study, (5) adding the method of collecting data, (6) adding the method of analyzing data, (7) minimizing the use of translation (L1) in teaching English, and (8) conducting the further study about the teachers' ability in using target language as a language of instruction.

\section{REFERENCES}

Ahmad, D., (2014). Understanding the 2013 Curriculum of English Teaching through the Teachers' and Policymakers' Perspectives. International Journal of Enhanced Research in Educational Development (IJERED). 2(4), 6-15. Retrieved on March 7, 2017 from https://pdfs.semanticscholar.org/dc45/ 58ac27a60ce91cb967f2b3f57d8720f37 91d.pdf.

Alhojailan, M. I., (2012). Thematic Analysis: A Critical Review of Its Process and Lingua Scientia | 68 
Evaluation. West East Journal of Social Sciences. 1(1), 39-47. Retrieved on May 3, 2018 from https://fac.ksu.edu.sa/sites/default/file s/ta_thematic_analysis_dr_mohammed _alhojailan.pdf.

Al-Musawi, N. M., (2014). Strategic Use of Translation in Learning English as a Foreign Language (EFL) among Bahrain University Students. Innovative Teaching. 3(4), 1-10. Retrieved on June 1, 2017 from http://journals.sagepub.com/doi/pdf/1 0.2466/10.03.IT.3.4.

Alrefaai, I. K., (2013). Suggested Guidelines for Using Translation in Foreign Language Learning and Teaching. International Research Journals. 4(1), 12-20. Retrieved on May 3, 2018 from https://www.interesjournals.org/article s/suggested-guidelines-for-usingtranslation-in-foreign-languagelearning-and-teaching.pdf.

Atmarizon, D. and Zaim, M., (2016). The Implementation of Scientific Approach in Teaching English at the Tenth Grade of Senior High School 7 Padang. Jurnal Pendidikan Bahasa, Sastra, dan Seni. 17(1), 1-18. Retrieved on June 1, 2017 from

http://ejournal.unp.ac.id/index.php/ko mposisi/article/view/8113/6197.

Bozorgian, H. \& Fallahpour, S., (2015). Teachers' and Students Amount and Purposes of L1 Use: English as Foreign Language (EFL) Classroom in Iran. Iranian Journal of Language Teaching Research. 3(2), 67-81. Retrieved on January 4, 2017 from http://www.urmia.ac.ir/sites/www.urm ia.ac.ir/files/\%285\%29.pdf.

Calis, E. and Dikilitas, K., (2012). The Use of Translation in EFL Classes as L2 Learning Practice. Procedia - Social and Behavioral Sciences 46. 5079-5084. Retrieved on March 7, 2017 from http://www.sciencedirect.com/ science/article/pii/S1877042812021258

Dagilienè, I., (2012). Translation as a Learning Method in English Language Teaching.
Studies about Languages. (21), 124129. Retrieved on March 7, 2017 from

http://www.kalbos.ktu.It/index.php/KS tud/article/viewFile/1469/2164.

Dewey, M. and Leung, C., (2010). English in English Language Teaching: Shifting Values and Assumptions in Changing Circumstances. Working Papers in Educational Linguistics. 25(1), 1-15. Retrieved on June 1, 2017 from https://pdfs.semanticscholar.org/e418/ 3e1a18327b92010ca4cd441ffb8ac15c1 423.pdf.

Djelloul, D. B. and Neddar, B. A., (2017). The Usefulness of Translation in Foreign Language Teaching: Teachers' Attitudes and Perceptions. Arab World English Journal for Translation \& Literary Studies. 1(3), 162-176. Retrieved on May 3, 2018 from http://dx.doi.org/10.24093/awejtls/vol 1no3.11.

Etikan, I., Musa, S. A., and Alkassim, R. S., (2016). Comparison of Convenience Sampling and Purposive Sampling. American Journal of Theoretical and Applied Statistics. 5(1), 1-4. Retrieved on May 3, 2018 from http://article.sciencepublishinggroup.c om/pdf/10.11648.j.ajtas.20160501.11. pdf.

Fraenkel, J. R., Wallen, N.E., and Hyun, H. H., (2012). How to Design and Evaluate Research in Education. $8^{\text {th }}$ Edition. New York: McGraw-Hill

Gani, S. A. and Mahjaty, R., (2017). English Teachers' Knowledge for Implementing the 2013 Curriculum. English Education Journal (EEJ). 8(2), 199-212. Retrieved on March 7, 2017 from http://www.jurnal.unsyiah.ac.id/EEJ/ar ticle/view/7228.

Guion, L. A., (2002). Triangulation: Establishing the Validity of Qualitative Studies. Institute of Food and Agricultural Sciences. 1-3. Retrieved on May 3, 2018 from https://sites.duke.edu/niou/files/2014/ 07/W13-Guion-2002-Triangulation-

Lingua Scientia | 69 
Establishing-the-Validity-of-QualitativeResearch.pdf.

Hales, D., (2010). An Introduction of Triangulation. Switzerland: UNAIDS 20, AVENUE APPIA.

Jadallah, M. and Hasan, F., (2017). A Review of Some New Trends in Using L1 in the EFL Classroom. 1-10. Retrieved on January 4, 2017 from https://pdfs.semanticscholar.org/0c53/ b4e4b805928868ca5199983b444d3e65 5fb2.pdf.

Karimian, Z. and Mohammadi, S., (2015). Teacher's Use of First Language in EFL Classrooms. Journal of Applied Linguistics and Language Research. 2(3), 61-71. Retrieved on June 1, 2017 from

http://webcache.googleusercontent.co $\mathrm{m} /$ search?q=cache:3yseVmzOuRUJ:ww w.jallr.com/index.php/JALLR/article/vie wFile/42/pdf_40+\&cd=1\&hl=id\&ct=clnk $\& g \mid=i d \& c l i e n t=$ firefox- $b-a b$.

Karimian, Z. and Talebinejad, M. R., (2013). Students' Use of Translation as a Learning Strategy in EFL Classroom. Journal of Language Teaching and Research. 4(3), 605-610. Retrieved on March 7, 2017 from http://www.academypublication.com/i ssues/past/jltr/vol04/03/21.pdf.

Klein, T. and Olbrecht, M., (2011). Triangulation of Qualitative and Quantitative Methods in Panel Peer Review Research. International Journal for Cross-Disciplinary Subjects in Education (IJCDSE). 2, 342-348. Retrieved on May 4, 2018 from file:///C:/Users/ACER/Downloads/Trian gulation_of_Qualitative_and_Quantitat ive_Meth.pdf.

Larson, M. L., (1984). Meaning-Based Translation. London: University Press of America.

Lasagabaster, D., (2013). The Use of the L1 in CLIL Classes: The Teachers' Perspective. Latin American Journal of Content and Language Integrated Learning. 6(2), 121. Retrieved on May 4, 2018 from http://laclil.unisabana.edu.co/index.ph p/LACLIL/article/view/3148.

Leonardi, V., (2011). Pedagogical Translation as a Naturally-Occurring Cognitive and Linguistic Activity in Foreign Language Learning. Annali Online di Lettere Ferrara. 1(2), 17-28. Retrieved on April 11, 2017 from http://annali.unife.it/lettere/article/vie wFile/234/183.

Mahmutoğlu, H. and Kicir, Z., (2013). The Use of Mother Tongue in EFL Classrooms. EUL Journal of Social Sciences. 4(1), 49-72. Retrieved on January 20, 2017 from https://www.sciencedirect.com/scienc e/article/pii/S1877042815044973.

Mart, C. T., (2013). The Facilitating Role of L1 in ESL Classes. International Journal of Academic Research in Business and Social Sciences. 3(1), 9-14. Retrieved on January 20, 2018 from http://www.hrmars.com/admin/pics/1 400.pdf.

Mattarima, K. and Hamdan, A. R., (2011). Learners' Motivation and Learning Strategies in English Foreign Language (EFI) in Indonesian Context. Journal of Edupres. 1, 100-108. Retrieved on April 9, 2017 from eprints.utm.my/15931/1/JOE-12011014.pdf.

Maxwell, J. A., (2005). Qualitative Research Design: An Interactive Approach. $2^{\text {nd }}$ Edition. London: SAGE Publications.

Mohamed, J. M. G., (2014). Use of Translation in the Classroom by EFL Teachers in Libya (A descriptive study). Arab World English Journal. (3), 27-40. Retrieved on May 3, 2018 from https://www.researchgate.net/publicat ion/308633917_Use_of_Translation_in _the_Classroom_by_EFL_Teachers_in_L ibya_A_descriptive_study.

Mollaei, F., Taghinezhad, A., and Sadighi, F., (2017). Teachers and Learners' Perceptions of Applying Translation as a Method, Strategy, or Technique in an Iranian EFL Setting. International Journal of Education \& Literacy Studies. 5(2), 67-73. Retrieved on April 18, 2017

Lingua Scientia | 70 
from

https://www.researchgate.net/profile/

Ali_Taghinezhad2/publication/3165971

62_Teachers_and_Learners\%27_Percep tions_of_Applying_Translation_as_a_M ethod_Strategy_or_Technique_in_an_Ir anian_EFL_Setting/links/5906396bOf7e 9bc0d590f82e/Teachers-and-LearnersPerceptions-of-Applying-Translation-asa-Method-Strategy-or-Technique-in-anIranian-EFL-Setting.pdf.

Munir, A., (2015). Claims of Scientific Approach in An English Lesson Transcript. 91-105. Retrieved on May 4, 2018 from https://ejournal.fbs.unesa.ac.id/index.p hp/Paramasastra/article/viewFile/39/4 4.

Musfiqon, H. and Nurdyansyah, (2015). Pendekatan Pembelajaran Saintifik. Sidoarjo: Nizamia Learning Center. Retrieved on January 20, 2017 from http://eprints.umsida.ac.id/306/1/BUk u\%20Saintifik.pdf.

Nur, M. R. and Madkur, A., (2014). Teachers' Voices on the 2013 Curriculum for English Instructional Activities. Indonesian Journal of English Education. 1(2), 119-134. Retrieved on March 7, 2017 from http://journal.uinjkt.ac.id/ijee/article/vi ewFile/1340/1189.

Ospina, S., (2004). Qualitative Research. Encyclopedia of Leadership. Retrieved on May 4, 2018 from http://ualr.edu/interdisciplinary/files/2 010/03/Qualitative_Research.pdf.

Pan, Yi-chun and Pan, Yi-ching, (2012). The Use of Translation in the EFL Classroom. Philippine ESL Journal. 9, 4-23. Retrieved on March 7, 2017 from http://www.philippine-esl-

journal.com/wpcontent/uploads/2014/01/V9-A1.pdf.

Raju, E. R. B., (2016). Translation as a Catalyst in an EFL Classroom. Journal of the English Literature Society, an International Open Access Refereed Research Journal. 1(3), 184-191. Retrieved on March 7, 2017

from
https://www.els.ngo/jels/2455-393X34.pdf.

Rini, J. E., (2014). English in Indonesia: Its Position Among Other Languages in Indonesia. Beyond Words. 2(2), 19-40. Retrieved on April 9, 2017 from http://jurnal.wima.ac.id/index.php/BW /article/viewFile/591/654.

Rudy, P. C., (2014). The perspective of curriculum in Indonesia on environmental education. International Journal of Research Studies in Education. 4(1), 77-83. Retrieved on March 7, 2017 from http://citeseerx.ist.psu.edu/viewdoc/d ownload;jsessionid $=52$ A70553B0437B9 AF3ECF0D1321318FB?doi=10.1.1.658.2 908\&rep=rep1\&type $=$ pdf.

Samardali, M. F. S. and Ismael, A. M. H., (2017). Translation as a Tool for Teaching English as a Second Language. Journal of Literature, Languages and Linguistics. 40, 64-69. Retrieved on May 3, 2018 from http://iiste.org/Journals/index.php/JLLL /article/viewFile/40072/41218.

Shofwan, M. I., (2016). The Use of Scientific Approach in Teaching English as a Foreign Language in SMPN I Jakarta. The $5^{\text {th }}$ ELTLT Conference Proceedings. 424-428. Retrieved on January 20, 2017 from

http://proceedings.id/index.php/elttt/a rticle/download/77/75.

Soleimani, H. and Heidarikia, H., (2017). The Effect of Translation as a Noticing Strategy on Learning Complex Grammatical Structures by EFL Learners. Applied Linguistics Research Journal. 1(1), 1-12. Retrieved on June 1, 2017 from http://www.alrjournal.com/article_519 16_e54afdf5966d18ea0ae6fe274eb2b8 1e.pdf.

Suandi, I. N., Agung, A. A. G., Candiasa, I. M., Suastra, I. W., Tika, I. N., Pageh, I. M., and Dantes, G. R., (2016). Pedoman Penulisan Karya Ilmiah Tugas Akhir, Skripsi, Tesis, dan Disertasi. Singaraja: UNDIKSHA PRESS.

Lingua Scientia | 71 
Suharyadi, (2013). Exploring "Scientific Approach" in English Language Teaching. Retrieved on January 4, 2017 from http://sastra.um.ac.id/wpcontent/uploads/2014/10/Exploringscientific-approach-in-english-languageteaching-proceding.pdf.

Tantra, D. K., (2015). Teaching English as a Foreign Language in Indonesia: a Literature Review. Lingual: Journal of Language and Culture. 4(1), 1-5. Retrieved on April 9, 2016 from http://download.portalgaruda.org/artic le. php?article $=411235 \&$ val $=7677 \&$ title

Wei, L., (2017). Translanguaging as a Practical Theory of Language. Applied Linguistics. 39(1), 9-30. Williams, C., (2007). Research Methods. Journal of Business \& Economic Research. 5(3), 65-72. Retrieved on November 5, 2016 from www.cluteinstitute.com/ojs/index.php/ JBER/article/download/2532/2 578.

Yeasmin, S. and Rahman, K. F., (2012). 'Triangulation' Research Method as the Tool of Social Science Research. BUP JOURNAL. 1, 154-163. Retrieved on May 4, 2018 from http://bup.edu.bd/assets/uploads/jour nal_content_file/1511259502154163.pdf.

Yulia, Y., (2013). Teaching Challenges in Indonesia: Motivating Students and Teachers' Classroom Language. Indonesian Journal of Applied
=TEACHING\%20ENGLISH\%20AS\%20A\% 2OFOREIGN\%2OLANGUAGE\%20IN\%20I NDONESIA:\%20A\%20LITERATURE\%20R EVIEW578.

Wahyudin, A. Y. and Sukyadi, D., (2015). A Closer Look at the Implementation of the Curriculum 2013 in Indonesia: Should the Scientific Approach Be Used in EFL Classroom?. Research Journal of Earth Science. 2(2). 56-70. Retrieved on January 4, 2017 from http://rjes.rsu.ac.th/Article/Article_J_A rticle_RJES_V2N2_56-70.pdf.

Linguistics. 3(1), 1-16. Retrieved on April 23, 2017 from https://www.researchgate.net/publicat ion/273529329_Teaching_challenges_i n_Indonesia_Motivating_students_and _teachers\%27_classroom_language.

Zaim, M., (2017). Implementing Scientific Approach to Teach English at Senior High School in Indonesia. Asian Social Science. 13(2), 33-40. Retrieved on April 23, 2017 from http://www.ccsenet.org/journal/index. php/ass/article/viewFile/64125/35595.

Zhao, Y., (2015). Using translation in ESL classrooms: An Asian perspective. International Journal of Innovative Interdisciplinary Research. 2, 38-51. Retrieved on March 7, 2017 from www.auamii.com/jiir/Vol-02/issue04/4Zhao.pdf. 